\title{
PENGARUH TINGKAT PENGGUNAAN PAKAN PENGUAT TERHADAP PERFORMA INDUK KAMBING BLIGON DI PETERNAK RAKYAT
}

\section{THE EFFECT OF FEED SUPPLEMENT LEVEL ON THE PERFORMANCE OF BLIGON DOES KEPT BY SMALL FARMERS}

\author{
Nuraini $^{1 *}$, I Gede Suparta Budisatria ${ }^{2}$, dan Ali Agus ${ }^{2}$ \\ ${ }^{1}$ Balai Pengkajian Teknologi Pertanian (BPTP) Kepulauan Bangka Belitung, Jl. Mentok Km. 4, Pangkalpinang, 33134 \\ ${ }^{2}$ Fakultas Peternakan, Universitas Gadjah Mada, Jl. Fauna No. 3 Bulaksumur, Yogyakarta, 55281
}

\section{INTISARI}

Penelitian ini bertujuan untuk mengetahui pengaruh tingkat penggunaan pakan penguat untuk perbaikan pakan terhadap performa induk kambing Bligon. Materi yang digunakan adalah 28 ekor induk kambing Bligon umur 1,5-2 tahun dengan rata-rata bobot badan awal 30,25 $\pm 8,05 \mathrm{~kg}$, pakan hijauan berupa ramban yang biasa digunakan oleh peternak dan pakan penguat. Ternak dikelompokkan kedalam 4 macam perlakuan pemberian pakan. Perlakuan ini meliputi : $\mathrm{P} 1$ = pakan kontrol (hijauan yang biasa diberikan peternak); $\mathrm{P} 2=$ pakan kontrol $+17 \%$ pakan penguat; $\mathrm{P} 3=$ pakan kontrol $+35 \%$ pakan penguat dan $\mathrm{P} 4=$ pakan kontrol $+52 \%$ pakan penguat. Penelitian berlangsung selama 8 bulan. Pakan yang diberikan sebanyak 3\% dari bobot badan berdasarkan bahan kering dan air minum diberikan secukupnya. Variabel yang diamati adalah konsumsi pakan, pertambahan bobot badan harian, feed conversion ratio, dan feed cost per gain. Data dianalisis menggunakan Rancangan Acak Lengkap pola searah. Hasil penelitian menunjukkan bahwa perbaikan pakan dapat meningkatkan $(\mathrm{P}<0,05)$ konsumsi pakan, pertambahan bobot badan harian, feed conversion ratio dan feed cost per gain. Rerata pertambahan bobot badan harian induk kambing Bligon antara P1, P2, P3 dan P4 berturut-turut yaitu 30,16; 11,11; 34,92 dan 34,92 g/ekor/hari, feed conversion ratio berturut-turut adalah 8,79; 16,37; 5,53 dan 7,97, feed cost per gain berturut-turut adalah Rp33.903,58; Rp86.691,35; Rp36.908,25 dan Rp47.412,19. Disimpulkan bahwa perbaikan pakan dengan pemberian pakan penguat akan meningkatkan pertambahan bobot badan harian pada aras $35 \%$ dan 52\%, feed conversion ratio, dan feed cost per gain pada induk kambing Bligon paling efisien masing-masing pada aras $35 \%$ dan tanpa pemberian pakan penguat.

(Kata kunci: Kambing Bligon, Pakan penguat)

\begin{abstract}
This study was conducted to evaluate the effects of concentrate supplement level for feed quality improvement on the performance of Bligon does. Twenty eight of 1.5-2 years old of Bligon does with an average initial body weight of $30.25 \pm 8.05 \mathrm{~kg}$, feed supplement and roughages which was regularly offered to the goats, were used in this study. The does were divided into four treatments groups of feed supplementation. Treatment P1 was control, doe was given roughages without concentrate supplementation, treatment $P 2$ was roughages with $17 \%$ concentrate supplementation, treatment P3 was roughages with $35 \%$ concentrate supplementation and treatment P4 was roughages with 52\% concentrate supplementation. The study was conducted for 8 months. Feed was given 3\% of body weight on dry matter base, while drinking water was given in sufficient. The data were consisted of feed intakes, average daily gain of does, feed conversion ratio and feed cost per gain. One way analysis of variance was used to analyze the data and continued by Duncans' New Multiple Range Test (DMRT) for significant differences. The result showed that improvement of feed increased $(P<0.05)$ feed intake, average daily gain, feed conversion and feed cost per gain of does. The average daily gain of does on P1; P2; P3; and P4 were 30.16; 11.11; 34.92 and $34.92 \mathrm{~g} /$ head/day respectivelly, while, feed conversion ratio were 8.79; 16.37; 5.53 and 7.97 respectively, feed cost per gain were Rp33.903,58; Rp86.691,35; Rp36.908,25 and Rp47.412,19. It is concluded that improving feed for does using concentrate supplementation increase the average daily gain on level of $35 \%$ and $52 \%$ concentrate supplementation, the best of feed conversion ratio and feed cost per gain of Bligon does respectively at the level of $35 \%$ and without concentrate supplementation.
\end{abstract}

(Keywords: Bligon goat, Concentrate supplementation)

\footnotetext{
* Korespondensi (corresponding author):

Telp. +62 81390045595

E-mail: noenoenk_sky@yahoo.co.id
} 


\section{Pendahuluan}

Kambing Bligon merupakan salah satu jenis kambing yang ditinjau dari segi eksteriornya merupakan persilangan antara kambing Kacang dan kambing Ettawa. Performa kambing ini mirip antara kambing Kacang dan kambing Ettawa dan termasuk dalam kelompok kambing Peranakan Ettawa (PE) (Hardjosubroto, 1994), namun persentase darah kambing Kacang lebih tinggi yaitu lebih dari 50\% (Sarwono, 2007). Kambing Bligon banyak tersebar di pantai utara Jawa dan di daerah Gunungkidul, Yogyakarta (Fitriani, 2008).

Pakan ruminansia pada umumnya terdiri atas hijauan dan konsentrat. Hijauan adalah bagian maerial dari tanaman terutama rumput dan legume (kacang-kacangan) yang mengandung SK 18\% atau lebih dalam bahan kering yang dapat digunakan sebagai makanan ternak (Hartadi et al., 1997). Murtidjo (1993) menambahkan bahwa konsentrat untuk kambing umumnya disebut sebagai pakan penguat atau bahan baku pakan yang memiliki kandungan serat kasar kurang dari $18 \%$ dan mudah dicerna.

Pakan penguat adalah bahan pakan yang mengandung serat kasar kurang dari 18\%, banyak mengandung bahan ekstrak tanpa nitrogen (BETN) dan sangat mudah dicerna. Termasuk dalam kelompok ini adalah golongan biji-bijian dan hasil sisa penggilingan (Tillman et al., 1998). Berdasarkan kandungan proteinnya, pakan penguat dapat dibedakan menjadi dua golongan yaitu pakan penguat sumber energi dan pakan penguat sumber protein (Harris et al., 1972 cit. Rivai, 2000). Utomo dan Soejono (1999) menyatakan bahwa pakan penguat dapat dibedakan menurut kandungan proteinnya yaitu pakan penguat sumber protein dengan kandungan protein kasar $20 \%$ atau lebih, serat kasar kurang dari $18 \%$, dinding sel kurang dari $35 \%$ dan pakan penguat sumber energi yaitu pakan dengan kandungan protein kasar kurang dari 20\%, serat kurang dari $18 \%$ serta dinding sel kurang dari $35 \%$.

Penambahan pakan penguat ke dalam pakan basal hijauan pada ruminansia dapat meningkatkan konsumsi pakan sehingga secara kualitas maupun kuantitas akan mampu memenuhi kebutuhan ternak akan nutrien yang diperlukan. Penambahan pakan penguat juga menjamin ketersediaan energi maupun nutrien bagi kehidupan mikrobia rumen (Sumoprastowo, 1993).

Pendapatan petani dari usaha ternak kambing Bligon pada umumnya masih relatif rendah, hal ini disebabkan oleh beberapa kendala antara lain jarak beranak yang terlalu panjang, angka kematian yang tinggi pada anak yang baru lahir, rendahnya kualitas pakan yang diberikan, kemampuan permodalan yang rendah serta kurangnya motivasi petani dalam menerapkan anjuran yang diberikan petugas. Penyebab utama rendahnya produktivitas induk kambing Bligon adalah kurangnya asupan nutrisi/pakan terutama pada musim kemarau panjang.

Penggunaan pakan basal berkualitas tinggi seperti pemberian konsentrat dapat dinaikkan pada kondisi musim kemarau, sejalan dengan menurunnya konsumsi hijauan (Kuswandi dan Thalib, 2005), lebih lanjut ditambahkan bahwa pertumbuhan kambing PE lepas sapih yang diberi pakan konsentrat terbatas dan rumput gajah secara ad libitum mampu mencapai pertumbuhan 36,5 $\mathrm{g} /$ hari, jauh lebih baik dibanding pertumbuhan kambing Kacang yang hanya 19,8 g/hari. Kambing lebih menyukai daun-daunan atau rambanan dari pada rumput sehingga diharapkan dapat mempertahankan pertumbuhan yang baik (Kuswandi et al. 2000). Berdasarkan hasil penelitian Marjuki (2008) didapatkan bahwa penggunaan tepung ikan sebanyak $10 \mathrm{~kg}$ dalam $100 \mathrm{~kg}$ pakan dapat meningkatkan efisiensi pemanfaatan pakan konsentrat dan pertambahan bobot badan pada kambing.

Menurut penelitian Iswoyo dan Widiyaningrum (2008), pemberian konsentrat dan hijauan dengan diberi jarak waktu yang berbeda $(0,2$, dan 4 jam), menghasilkan pertambahan bobot badan harian (PBBH) berturut-turut 44,08, 46,28, dan 43,31 g/ekor/hari, sedangkan berdasarkan penelitian Tahuk (2008) menunjukkan bahwa kambing Bligon jantan berumur sekitar 10-12 bulan yang digemukkan dengan aras protein yang berbeda (aras PK dalam ransum 9, 11, 13, dan 15\%) mampu menghasilkan PBBH yang tinggi berturut-turut 92, 106, 92, dan $114 \mathrm{~g} /$ ekor/hari.

Sehubungan dengan uraian di atas maka perlu dilakukan penelitian untuk mengatasi ketersediaan hijauan yang tidak stabil tersebut dan untuk meningkatkan kualitas pakan agar dapat memenuhi kebutuhan nutrisi untuk produksi daging maupun reproduksi, penambahan pakan suplementasi berupa pakan penguat diharapkan akan dapat meningkatkan konsumsi pakan ternak yang pada akhirnya berpengaruh terhadap performa pada induk kambing Bligon. Tujuan penelitian adalah untuk mengetahui sejauh mana pengaruh tingkat penggunaan pakan penguat untuk peningkatan performa induk kambing Bligon yang dipelihara di peternak rakyat yang meliputi konsumsi pakan, pertambahan bobot badan harian induk kambing Bligon, feed conversion ratio serta feed cost per gain. 


\section{Materi dan Metode}

\section{Materi}

Materi yang digunakan berupa ternak sebanyak 28 ekor induk kambing Bligon berumur sekitar 1,5-2 tahun dengan rata-rata bobot badan awal 30,25 $\pm 8,05 \mathrm{~kg}$. Bahan-bahan yang digunakan dalam penyusunan ransum adalah hjauan berupa bahan pakan lokal (rambanan) dan pakan penguat berupa pakan penguat komersial. Pakan yang digunakan dalam penelitian ini disusun atas dasar kebutuhan kambing dengan bobot badan 12-45 kg.

Peralatan yang digunakan berupa perlengkapan kandang yaitu tempat pakan untuk pakan penguat dan tempat air minum, timbangan merk FHK ${ }^{\circledR}$ kapasitas $1200 \mathrm{~kg}$ dengan kepekaan $1 \mathrm{~kg}$ untuk menimbang bobot badan kambing, timbangan pakan kapasitas $2 \mathrm{~kg}$ dengan kepekaan $10 \mathrm{~g}$ untuk menimbang pakan, seperangkat alat laboratorium, serta bahan kimia untuk analisis proksimat.

\section{Metode}

Penelitian ini dilaksanakan selama delapan bulan, dimulai bulan Juni 2011 sampai dengan Januari 2012. Penelitian dilakukan di kelompok peternak kambing Bligon Purwo Manunggal yang berlokasi di dusun Jerukan, Desa Giri Sekar, Kecamatan Panggang, Kabupaten Gunungkidul, Daerah Istimewa Yogyakarta. Analisis pakan dilaksanakan di Laboratorium Kimia, Pusat Studi Pangan dan Gizi (PSPG), Universitas Gadjah Mada, Yogyakarta. Rancangan percobaan pada penelitian ini menggunakan Rancangan Acak Lengkap pola searah (RAL) dengan teknik sampling yang dilakukan menggunakan random sampling.
Prapenelitian. Pakan yang diberikan berupa hijauan dan pakan penguat. Hijauan diberikan dalam keadaan segar, yang biasa diberikan oleh peternak, didapatkan di sekitar lokasi penelitian. Pakan penguat yang diberikan dianalisis proksimat untuk menentukan kandungan nutrisi pakan (Tabel 1).

Pengelompokan kambing. Kambing dikelompokkan dalam 4 macam perlakuan pemberian pakan sesuai dengan perlakuan dengan jumlah ulangan ternak tiap kelompok perlakuan adalah 7 ekor ternak. Setiap kandang diberi kode perlakuan dan masing-masing kambing ditempatkan secara acak.

Induk kambing Bligon diberikan pakan hijauan menggunakan sumber pakan lokal (rambanan). Untuk memenuhi kebutuhan pakan ternak ditambahkan pakan penguat sehingga diperoleh pakan standar. Adapun perlakuan pada penelitian ini meliputi :

$\mathrm{P} 1=$ pakan ramban $+0 \%$ pakan penguat

$\mathrm{P} 2=$ pakan ramban $+17 \%$ pakan penguat

P3 $=$ pakan ramban $+35 \%$ pakan penguat

$\mathrm{P} 4=$ pakan ramban $+52 \%$ pakan penguat

Penelitian berlangsung selama delapan bulan dan masa adaptasi terhadap lingkungan dan pakan perlakuan dilakukan selama kurang lebih 2 minggu sebelumnya. Pakan yang diberikan sebanyak 3\% dari bobot badan berdasarkan bahan kering, sedangkan air minum diberikan secukupnya.

Penimbangan ternak dilakukan per individu ternak pada awal penelitian, selanjutnya penimbangan dilakukan setiap 1 bulan sekali untuk menyesuaikan jumlah pakan yang diberikan, dan

Tabel 1. Komposisi nutrien pakan (nutrient composition of feed)

\begin{tabular}{lccccc}
\hline \multirow{2}{*}{\multicolumn{1}{c}{ Bahan pakan (feed ingredient) }} & \multicolumn{5}{c}{ Dalam 100\% BK (DM bases) } \\
\cline { 2 - 6 } & $\mathrm{BK}^{\mathrm{a}}$ & $\mathrm{LK}^{\mathrm{a}}$ & $\mathrm{PK}^{\mathrm{a}}$ & $\mathrm{SK}^{\mathrm{a}}$ & $\mathrm{TDN}^{\mathrm{b}}$ \\
\hline Pakan penguat (feed supplementation) & 88,30 & 3,37 & 13,15 & 27,09 & 50,42 \\
Rekotok (nama lokal) (local name) & 56,98 & 5,98 & 11,69 & 14,01 & 75,14 \\
Kilayu (Erioglossum rubiginosum) & 50,57 & 5,60 & 13,17 & 30,41 & 60,04 \\
Sambang pantek (nama lokal) (local name) & 30,40 & 3,52 & 9,77 & 21,84 & 58,24 \\
Lombokan (nama lokal) (local name) & 58,39 & 5,49 & 13,06 & 29,69 & 58,24 \\
Pingganan (Protris laevigata) & 48,97 & 6,39 & 12,63 & 20,21 & 68,47 \\
Popohan (nama lokal) (local name) & 54,59 & 2,29 & 9,91 & 17,57 & 60,76 \\
\hline
\end{tabular}

BK: bahan kering (DM: dry matter), LK: lemak kasar (EE: extract ether), PK: protein kasar (CP: crude protein), SK: serat kasar (CF: crude fiber), TDN: total digestible nutrient.

a Hasil analisis proksimat di Laboratorium Kimia Pusat Studi Pangan dan Gizi, Universitas Gadjah Mada (2011) (proximate analysis result in chemical laboratory and nutrition center Gadjah Mada University (2011)).

b Hasil perhitungan rumus regresi tabel komposisi pakan Hartadi et al. (1990) (the calculation of the regression feed composition tables Hartadi et al. (1990)). 
untuk mendapatkan pertambahan bobot badan harian (PBBH) ternak. Konsumsi pakan baik hijauan maupun pakan penguat dihitung setiap hari sekali. Pakan yang diberikan ditimbang dan dicatat, demikian pula sisa pakan untuk mengetahui jumlah konsumsi pakan.

\section{Pengambilan data}

Data yang diambil dalam penelitian ini adalah konsumsi pakan meliputi konsumsi bahan kering (BK), protein kasar ( $\mathrm{PK})$, dan total digestible nutrients (TDN), $\mathrm{PBBH}$ induk, feed conversion ratio, dan feed cost per gain induk kambing Bligon.

Konsumsi pakan. Konsumsi pakan meliputi konsumsi BK, PK, dan TDN. Konsumsi pakan segar dihitung dengan mengurangi jumlah pakan yang diberikan dengan sisa pakan. Sebelumnya, pakan ditimbang terlebih dahulu sedangkan sisa pakan ditimbang pada pagi berikutnya.

Konsumsi BK pakan dihitung dengan mengalikan konsumsi pakan segar dengan kandungan BK pakan, sedangkan konsumsi PK dihitung dengan mengalikan konsumsi BK dengan kandungan PK pakan. Dalam penelitian ini komposisi kimia sisa pakan tidak dianalisis. Nutrien sisa pakan yang seharusnya dianalisis tetapi tidak dilakukan sehingga menggunakan asumsi kandungan nutrisi sisa pakan adalah sama dengan kandungan nutrisi pakan yang diberikan.

Konsumsi TDN (\%) dihitung dengan persamaan Hartadi et al. (1990):

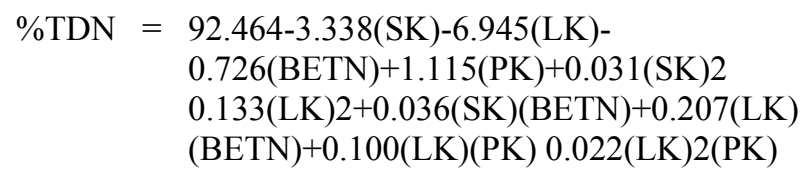

Keterangan: SK: serat kasar, LK: lemak kasar, BETN: bahan ekstrak tanpa nitrogen, PK: protein kasar.

\section{Pertambahan bobot badan harian (PBBH).} Pertambahan bobot badan harian dihitung berdasarkan selisih antara bobot badan akhir dengan bobot badan awal penelitian dibagi jumlah hari penelitian.

Feed conversion ratio (FCR). Feed conversion ratio atau konversi pakan didapat dengan cara menghitung jumlah BK pakan yang dikonsumsi per hari dibagi dengan $\mathrm{PBBH}$.

Feed cost per gain. Feed cost per gain atau biaya pakan yang dibutuhkan untuk menghasilkan $1 \mathrm{~kg}$ bobot badan, dihitung dengan cara membagi biaya pakan yang dikeluarkan dengan kenaikan bobot badan dan dinyatakan dalam rupiah $/ \mathrm{kg}$.

\section{Analisis data}

Data yang terkumpul dianalisis menggunakan analisis variansi pola searah (oneway ANOVA), apabila terdapat perbedaan signifikan, dilanjutkan dengan uji jarak berganda Duncan's new Multiple Range Test (DMRT).

\section{Hasil dan Pembahasan}

\section{Konsumsi pakan kambing Bligon}

Hasil analisis konsumsi BK, PK, dan TDN pada induk kambing Bligon dengan perlakuan penambahan pakan penguat menunjukkan adanya pengaruh yang nyata dari masing-masing perlakuan.

Konsumsi bahan kering (BK). Hasil analisis statistik menunjukkan bahwa konsumsi BK per bobot badan metabolik ( $\mathrm{g} / \mathrm{kg}$ BBM) per hari dari keempat perlakuan menunjukkan perbedaan $(\mathrm{P}<0,05)$. Rerata konsumsi BK yaitu 35,73; 52,74; 23,59 dan $32,35 \mathrm{~g} / \mathrm{kg}$ BBM berturut-turut untuk pemberian pakan penguat $0,17,35$, dan $52 \%$ (Tabel 1). Rerata konsumsi BK pakan dari keempat perlakuan terlihat bahwa P2 menunjukkan hasil lebih tinggi dibandingkan dengan perlakuan lainnya. Hasil ini mengindikasikan bahwa penambahan pakan penguat sebesar $20 \%$ pada P2 meningkatkan konsumsi BK dibandingkan perlakuan lainnya, hal ini kemungkinan disebabkan ketersediaan pakan rambanan di lokasi penelitian cukup tinggi, sehingga penambahan pakan penguat yang hanya sebesar $20 \%$ mengakibatkan kenaikan konsumsi BK dibandingkan perlakuan lainnya.

Berdasarkan hasil penelitian Ramadhan et al. (2013) dengan perlakuan imbangan hijauan konsentrat yang berbeda didapatkan konsumsi BK masing-masing 1,718; 1,482; dan 1,366 kg/ekor/hari berturut-turut untuk penggunaan pakan penguat 17 , 35 , dan $52 \%$, sedangkan nilai konsumsi BK pada penelitian Serment et al. (2011) yang menggunakan kambing Saanen dengan perlakuan konsentrat 35\%, yaitu sebesar 2,68 kg/ekor/hari. Terlihat bahwa terdapat beberapa faktor yang menyebabkan perlakuan perbaikan pakan tidak mempengaruhi konsumsi BK. Menurut Purbowati et al. (2003) pemberian konsentrat yang terlalu banyak akan menyebabkan konsentrasi energi ransum meningkat, sehingga dapat menurunkan tingkat konsumsi, selanjutnya dilaporkan bahwa peningkatan aras konsentrat justru menurunkan konsumsi BK pakan. Hasil yang sama juga disampaikan oleh Serment et al. (2011) bahwa konsumsi BK tidak dipengaruhi oleh persentase konsentrat. Ditambahkan Arora (1995) bahwa konsumsi BK pakan dipengaruhi oleh bobot badan, temperatur lingkungan, dan karakteristik pakan yang meliputi kecernaan, 
palatabilitas, dan keseimbangan nutrien dalam ransum.

Rerata BK penelitian menunjukkan bahwa konsumsi $\mathrm{BK}(\mathrm{g} / \mathrm{kg}$ BBM) untuk perlakuan P2 sudah sesuai dengan pendapat Devendra dan Burns (1994) yang menyatakan bahwa kambing pedaging lokal di daerah tropis yang diberi pakan sekenyangkenyangnya mempunyai konsumsi BK harian dalam kisaran 1,8 sampai $3,8 \%$ dari bobot badan setara dengan 40,5 sampai $127,3 \mathrm{~g} / \mathrm{kg} \quad \mathrm{BBM} / \mathrm{hari}$, sedangkan untuk perlakuan P1, P3, dan P4 hasilnya masih lebih rendah dari kisaran yang disarankan.

Konsumsi BK tertinggi dicapai pada P2 yaitu penambahan pakan penguat $17 \%$ yang mengakibatkan meningkatnya konsumsi BK karena laju pakan di dalam saluran pencernaan menjadi lebih cepat. Hal ini sesuai dengan pendapat Tillman et al. (1998) yang menyatakan bahwa pakan penguat merupakan bahan pakan ternak yang mudah dicerna sehingga laju aliran pakan dalam saluran pencernaan lebih cepat dan memungkinkan ternak untuk menambah konsumsi pakan. Hasil penelitian di atas tidak sama dengan hasil penelitian Purbowati et al. (2003) dan Serment et al. (2011) yang menunjukkan bahwa konsumsi BK pakan tidak dipengaruhi oleh persentase konsentrat.

Konsumsi BK pada kambing banyak dipengaruhi oleh laju pencernaan bahan pakan dalam saluran pencernaan, laju pengeluaran sisa pakan yang dikonsumsi dan tingkat pemenuhan nutrien dari bahan pakan yang dikonsumsi (Tillman et al., 1998). Utomo dan Soejono (1999) menyatakan bahwa banyak sedikitnya konsumsi nutrien tergantung pada jumlah BK pakan yang dikonsumsi oleh ternak dan kandungan nutrien dalam pakan yang diberikan.

Konsumsi protein kasar (PK). Hasil analisis statistik menunjukkan bahwa perlakuan penambahan pakan penguat berpengaruh nyata $(\mathrm{P}<0,05)$ terhadap konsumsi PK. Rerata konsumsi PK per bobot badan metabolik (g/kg BBM) per ekor per hari dari keempat perlakuan adalah 4,$28 ; 6,87$; 2,90 dan 3,93 berturut-turut untuk P1, P2, P3 dan P4 (Tabel 1).

Konsumsi PK antara P1, P3, dan P4 tidak menunjukkan perbedaan yang nyata tetapi konsumsi PK pada P2 terlihat lebih tinggi dibandingkan perlakuan lainnya. Konsumsi PK pada perlakuan yang diberi penambahan konsentrat cenderung mengalami peningkatan, dengan konsumsi terendah pada P3 dan tertinggi pada P2. Konsumsi PK yang semakin meningkat disebabkan oleh konsumsi BK pada perlakuan juga meningkat, hal ini sangat berpengaruh terhadap konsumsi PK. Putra dan Puger (1995) menyatakan bahwa protein pakan berkorelasi positif dengan konsumsi BK, bahan organik, protein, dan energi. Menurut Purbowati et al. (2007), faktor yang mempengaruhi konsumsi PK adalah konsumsi BK dan kandungan PK pakan. Ditambahkan oleh Kamal (1997) bahwa banyaknya pakan yang dikonsumsi akan mempengaruhi besarnya nutrien lain yang dikonsumsi, sehingga semakin banyak pakan yang dikonsumsi akan meningkatkan konsumsi nutrien lain yang ada dalam pakan.

Konsumsi total digestible nutrients (TDN). Konsumsi TDN dipengaruhi secara nyata $(\mathrm{P}<0,05)$ oleh perlakuan perbaikan pakan melalui

Tabel 2. Rerata konsumsi bahan kering (BK), protein kasar (PK), dan total digestible nutrients (TDN) (average intakes of dry matter, crude protein and total digestible nutrients)

\begin{tabular}{|c|c|c|c|c|}
\hline \multirow{2}{*}{ Parameter } & \multicolumn{4}{|c|}{ Perlakuan pakan (feed treatment) } \\
\hline & P1 & P2 & P3 & P4 \\
\hline \multicolumn{5}{|c|}{ Konsumsi nutrien pakan (intake of feed nutrient) } \\
\hline \multicolumn{5}{|l|}{ Bahan kering (dry matter) } \\
\hline (kg/ekor/hari) (kg/head/day) & $2,47 \pm 0,31$ & $1,78 \pm 0,44$ & $1,86 \pm 0,51$ & $2,33 \pm 0,77$ \\
\hline$(\mathrm{g} / \mathrm{kg} \mathrm{BBM})(\mathrm{g} / \mathrm{kg} M B W)$ & $35,73 \pm 0,01^{\mathrm{a}}$ & $52,74 \pm 0,01^{\mathrm{b}}$ & $23,59 \pm 0,01^{\mathrm{a}}$ & $32,35 \pm 0,02^{\mathrm{a}}$ \\
\hline \multicolumn{5}{|l|}{ Protein kasar (crude protein) } \\
\hline (kg/ekor/hari) $(\mathrm{kg} / \mathrm{head} /$ day $)$ & $0,30 \pm 0,04$ & $0,24 \pm 0,05$ & $0,23 \pm 0,06$ & $0,28 \pm 0,09$ \\
\hline$(\mathrm{g} / \mathrm{kg} \mathrm{BBM})(\mathrm{g} / \mathrm{kg} M B W)$ & $4,28 \pm 0,001^{\mathrm{a}}$ & $6,87 \pm 0,002^{\mathrm{b}}$ & $2,90 \pm 0,001^{\mathrm{a}}$ & $3,93 \pm 0,002^{\mathrm{a}}$ \\
\hline \multicolumn{5}{|l|}{ TDN (total digestible nutrients) } \\
\hline (kg/ekor/hari) (kg/head/day) & $1,62 \pm 0,19$ & $1,15 \pm 0,27$ & $1,17 \pm 0,34$ & $1,45 \pm 0,50$ \\
\hline$(\mathrm{g} / \mathrm{kg} \mathrm{BBM})(\mathrm{g} / \mathrm{kg} M B W)$ & $23,36 \pm 0,01^{\mathrm{b}}$ & $33,89 \pm 0,01^{\mathrm{c}}$ & $14,89 \pm 0,004^{\mathrm{a}}$ & $20,14 \pm 0,01^{\mathrm{ab}}$ \\
\hline
\end{tabular}

MBW= metabolic body weight.

P1: $0 \%$ pakan penguat ( $0 \%$ concentrate supplement), $\mathrm{P} 2: 17 \%$ pakan penguat ( $17 \%$ concentrate supplement), P3: $32 \%$ pakan penguat ( $32 \%$ concentrate supplement), $\mathrm{P} 4: 52 \%$ pakan penguat (52\% concentrate supplement).

a,b,c Superskrip yang berbeda pada baris yang sama menunjukkan perbedaan $(\mathrm{P}<0,05)$ (different superscript at the same row indicate significant differences $(P<0.05))$. 
penambahan pakan penguat pada induk kambing. Rerata konsumsi TDN per bobot badan metabolik $(\mathrm{g} / \mathrm{kg}$ BBM) per ekor per hari dari keempat perlakuan yaitu 24,64; 36,48; 14,49 dan 22,59 berturut-turut untuk P1, P2, P3, dan P4 (Tabel 2). Perbedaan nyata konsumsi TDN antar perlakuan terjadi karena konsumsi BK yang juga berbeda nyata sehingga mengakibatkan konsumsi TDN ketiga perlakuan menjadi berbeda nyata.

Rerata konsumsi TDN (kg/ekor/hari) penelitian antara $\mathrm{P} 1, \mathrm{P} 2, \mathrm{P} 3$, dan $\mathrm{P} 4$ berturut-turut 1,$62 ; 1,15 ; 1,17$ dan $1,45 \mathrm{~kg} / \mathrm{ekor} /$ hari. Nilai ratarata konsumsi TDN (kg/ekor/hari) penelitian ini lebih tinggi dibanding NRC (1981) yang menyatakan bahwa kebutuhan energi untuk kambing dengan bobot badan $20 \mathrm{~kg}$ adalah $0,27 \mathrm{~kg}$ TDN atau 0,96 Mcal ME yang setara dengan $0,10 \mathrm{Mcal} / \mathrm{kg}$ BB. Pemenuhan kebutuhan energi sangat penting artinya bagi kelangsungan hidup ternak ruminansia.

Pertambahan bobot badan harian, feed conversion ratio, dan feed cost per gain induk kambing Bligon

Data rerata PBBH per ekor per hari, FCR, dan feed cost per gain induk kambing Bligon dari keempat perlakuan selama penelitian disajikan pada Tabel 3.

Pertambahan bobot badan harian. Perlakuan perbaikan pakan terhadap kambing Bligon berpengaruh nyata $(\mathrm{P}<0,05)$ terhadap $\mathrm{PBBH}$ induk kambing Bligon. Rerata PBBH antara P1, P2, P3, dan P4 berturut-turut yaitu 30,16; 11,11;34,92 dan 34,92 g/ekor/hari (Tabel 3). Data PBBH keempat perlakuan memperlihatkan bahwa ternak pada P2 mempunyai PBBH yang paling rendah dibandingkan dengan perlakuan lainnya. Hal ini dimungkinkan karena pada P2, konsumsi nutrien pakan (BK) relatif rendah dibandingkan dengan $\mathrm{P} 1$, P3, dan P4, sehingga PBBH yang dihasilkan juga rendah dan pertumbuhan dari induk kambing Bligon pada P2 lambat dibanding perlakuan lainnya sehingga PBBHnya juga rendah.
Secara keseluruhan hasil PBBH ini relatif rendah, hal ini disebabkan karena ketersediaan sumber hijauan di lokasi penelitian sangat tergantung oleh musim, sehingga dari segi kualitas, jenis, jumlah, dan cara pemberian pakan juga sangat bervariasi. Ketersediaan pakan penguat yang digunakan pada penelitian ini (Tabel 1) juga diduga turut berpengaruh terhadap PBBH yang dihasilkan. Sarwono (2007) menyatakan bahwa PBBH kambing yang digemukkan secara intensif bisa mencapai 100-150 g/ekor/hari dengan rata-rata 120 $\mathrm{g} /$ ekor/hari atau 700-1.050 g dengan rata-rata $840 \mathrm{~g}$ per minggu.

Feed conversion ratio (FCR). Perlakuan perbaikan pakan terhadap kambing Bligon berpengaruh nyata $(\mathrm{P}<0,05)$ terhadap FCR. Rerata FCR antara P1, P2, P3, dan P4 berturut-turut yaitu 8,$79 ; 16,37 ; 5,53$ dan 7,97 .

Nilai FCR dari keempat perlakuan menunjukkan perbedaan yang nyata pada P2 dibanding perlakuan lainnya. Hal ini dimungkinkan karena pada P2, konsumsi nutrien pakan (BK) relatif tinggi dibandingkan dengan $\mathrm{P} 1, \mathrm{P} 3$, dan $\mathrm{P} 4$, sedangkan $\mathrm{PBBH}$ pada $\mathrm{P} 2$ yang dihasilkan lebih rendah sehingga nilai dari FCR yang dihasilkan juga tinggi.

Nilai FCR dari keempat perlakuan terlihat bahwa ternak pada P3 lebih efisien dalam memanfaatkan pakan diikuti P4, P1, dan P2. Semakin kecil nilai konversi pakan berarti semakin efisien dalam pemanfaatan pakan. Basuki dan Ngadiyono (2000) menyatakan bahwa nilai konversi pakan semakin kecil semakin baik, sebaliknya nilai konversi pakan akan semakin jelek bila bertambah besar.

Feed cost per gain. Perlakuan perbaikan pakan terhadap kambing Bligon berpengaruh nyata $(\mathrm{P}<0,05)$ terhadap feed cost per gain. Rata-rata feed cost per gain antara $\mathrm{P} 1, \mathrm{P} 2, \mathrm{P} 3$ dan $\mathrm{P} 4$ berturut-turut yaitu Rp33.903,58; Rp86.691,35; Rp36.908,25 dan Rp47.412,19. Bila dilihat nilai feed cost per gain dari keempat perlakuan terlihat bahwa P2

Tabel 3. Rerata pertambahan bobot badan harian (g/ekor/hari), feed conversion ratio (FCR) dan feed cost per gain $(\mathrm{Rp} / \mathrm{kg}$ bobot badan) (the average of daily gain (g/head/day), feed conversion ratio (FCR) and feed cost per gain (Rp/kg body weight)

\begin{tabular}{lrrrr}
\hline \hline \multirow{2}{*}{ Parameter } & \multicolumn{4}{c}{ Perlakuan (treatment) } \\
\cline { 2 - 5 } & $\mathrm{P} 1$ & $\mathrm{P} 2$ & $\mathrm{P} 3$ & $\mathrm{P} 4$ \\
\hline PBBH (average daily gain) & $30,16^{\mathrm{b}}$ & $11,11^{\mathrm{a}}$ & $34,92^{\mathrm{b}}$ & $34,92^{\mathrm{b}}$ \\
Feed conversion ratio & $8,79^{\mathrm{a}}$ & $16,37^{\mathrm{b}}$ & $5,53^{\mathrm{a}}$ & $7,97^{\mathrm{a}}$ \\
Feed cost per gain & $33.903,58^{\mathrm{a}}$ & $86.691,35^{\mathrm{b}}$ & $36.908,25^{\mathrm{a}}$ & $47.412,19^{\mathrm{a}}$ \\
\hline
\end{tabular}

P1: $0 \%$ pakan penguat ( $0 \%$ concentrate supplement), $\mathrm{P} 2: 17 \%$ pakan penguat (17\% concentrate supplement), P3: $32 \%$ pakan penguat ( $32 \%$ concentrate supplement), $\mathrm{P} 4: 52 \%$ pakan penguat (52\% concentrate supplement).

${ }^{\text {a,b,c }}$ Superskrip yang berbeda pada baris yang sama menunjukkan perbedaan $(\mathrm{P}<0,05)$ (different superscript at the same row indicate significant differences $(P<0.05))$. 
menunjukkan perbedaan yang nyata dibandingkan dengan perlakuan lainnya. Nilai feed cost per gain pada penelitian ini paling tinggi pada perlakuan P2 diikuti P4, P3, dan P1 sehingga dari perlakuan di atas yang dinilai paling baik P1, P3, P4, dan P2. Beberapa hasil penelitian menunjukkan bahwa feed cost per gain pada kambing Bligon sangat bervariasi. Feed cost per gain sebesar Rp16.465,21 diperoleh pada penelitian yang dilakukan oleh Tahuk (2008), sedangkan berdasarkan penelitian Noor (2008), Sholikhin (2010), dan Nurazmil (2008) didapatkan feed cost per gain berturut-turut sebesar Rp20.816,00; Rp88.150,00 dan Rp29.541,00. Menurut Basuki dan Ngadiyono (2000), feed cost per gain adalah besarnya biaya pakan yang dibutuhkan untuk mendapatkan satu kilogram pertambahan bobot badan. Jika dalam suatu penggemukan ternak nilai feed cost per gain semakin rendah maka akan semakin baik.

\section{Kesimpulan}

Berdasarkan penelitian yang telah dilaksanakan dapat disimpulkan bahwa perbaikan pakan dengan pemberian pakan penguat dapat meningkatkan pertambahan bobot badan harian pada aras $35 \%$ dan $52 \%$, feed conversion ratio (FCR) dan feed cost per gain pada induk kambing Bligon paling efisien masing-masing pada aras $35 \%$ dan tanpa pemberian pakan penguat.

\section{Daftar Pustaka}

Arora, S. P. 1995. Pencernaan Mikroba pada Ruminansia. Terjemahan. Gadjah Mada University Press, Yogyakarta.

Ramadhan, B. G., T. H. Suprayogi, dan A. Sustiyah. 2013. Tampilan produksi susu dan kadar lemak susu kambing Peranakan Ettawa akibat pemberian pakan dengan imbangan hijauan dan konsentrat yang berbeda. Anim. Agric. J. 2: 353-361.

Basuki, P. dan N. Ngadiyono. 2000. Mekanisme Produksi pada Usaha Penggemukan Sapi. Fakultas Peternakan, Universitas Gadjah Mada, Yogyakarta.

Devendra, C. dan M. Burns. 1994. Produksi Kambing di Daerah Tropis. Penerbit ITB. Bandung.

Fitriani, Y. 2008. Konsumsi dan kecernaan nutrien induk kambing Bligon 8-14 minggu setelah beranak yang mendapatkan suplementasi sumber energi dan protein. Skripsi Sarjana Peternakan. Fakultas Peternakan. Universitas Gadjah Mada, Yogyakarta.
Hartadi, H., S. Reksohadiprodjo, dan A. D. Tillman. 1990. Tabel Komposisi Pakan untuk Indonesia. Cetakan ke-2. Gadjah Mada University Press. Yogyakarta.

Hartadi, H., S. Reksohadiprojo, dan A. D. Tillman. 1997. Tabel Komposisi Pakan untuk Indonesia. Cetakan ke-4. Gadjah Mada University Press, Yogyakarta.

Hardjosubroto, W. 1994. Aplikasi Pemuliabiakan Ternak di Lapangan. PT. Gramedia Widiasarana Indonesia, Jakarta.

Iswoyo dan Widiyaningrum. 2008. Pengaruh jarak waktu pemberian pakan konsentrat dan hijauan terhadap produktivitas kambing Peranakan Etawah lepas sapih. Jurnal Ilmiah Ilmu-Ilmu Peternakan 11: 70-74.

Kamal, M. 1997. Kontrol Kualitas Pakan. Fakultas Peternakan. Universitas Gadjah Mada, Yogyakarta.

Kuswandi, M. Martawidjaja, M. Zulbardi, B. Setiadi, dan D. B. Wiyono. 2000. Penggunaan $\mathrm{N}$ mudah tersedia dalam pakan basal rumput lapangan pada kambing lepas sapih. Jurnal Ilmiah Ternak Veteriner 5: 219223.

Kuswandi dan A. Thalib. 2005. Pertumbuhan kambing lepas sapih yang diberi konsentrat terbatas. Prosiding Seminar Nasional Teknologi Peternakan dan Veteriner. Pusat Penelitian dan Pengembangan Peternakan, Badan Penelitian dan Pengembangan Pertanian, Departemen Pertanian, Bogor.

Marjuki. 2008. Penggunaan tepung ikan dalam pakan konsentrat dan pengaruhnya terhadap pertambahan bobot badan kambing betina. Jurnal Ternak Tropika 9: 90-100.

Murtidjo, A. B. 1993. Memelihara Kambing sebagai Ternak Potong dan Perah. Kanisius. Yogyakarta.

Noor, A. R. 2008. Pertambahan bobot badan kambing Bligon jantan fase penggemukan dengan pakan tambahan dedak halus, tepung gaplek dan ampas tahu. Skripsi Sarjana Peternakan. Fakultas Peternakan, Universitas Gadjah Mada. Yogyakarta.

NRC. 1981. Nutrients Requirements of Goats : Angora, Dairy and Meat Goats in Temperate and Tropical Countries. National Academy Press, Washington. D. C.

Nurazmil, A. 2008. Pertambahan bobot badan kambing Bligon jantan yang diberi pakan dasar hijauan ditambah konsentrat tinggi. Skripsi Sarjana Peternakan. Fakultas Peternakan, Universitas Gadjah Mada, Yogyakarta. 
Purbowati, E., E. Baliarti, dan S. P. S. Budhi. 2003. Kondisi cairan rumen domba yang digemukkan secara feedlot dengan pakan dasar dan aras konsentrat berbeda. J. Indon. Anim. Agric. 28: 134-140.

Purbowati, E., C. I. Sutrisno, E. Baliarti, S. P. S. Budhi, dan W. Lestariana. 2007. Pengaruh pakan komplit dengan kadar protein dan energi yang berbeda pada penggemukan domba lokal jantan secara feedlot terhadap konversi pakan. Prosiding Seminar Nasional Teknologi Peternakan dan Veteriner. Pusat Penelitian dan Pengembangan Peternakan, Badan Penelitian dan Pengembangan Pertanian, Departemen Pertanian, Bogor.

Putra, S. dan A. W. Puger. 1995. Manipulasi Mikroba dalam Fermentasi Rumen Salah Satu Alternatif untuk Meningkatkan Efisiensi Penggunaan Zat-zat Makanan. Fakultas Peternakan, Universitas Udayana, Denpasar.

Rivai, A. F. 2000. Pengaruh pemberian pakan basal yang berbeda dengan suplementasi konsentrat terhadap komposisi kimia biceps femoris sapi Peranakan Ongole. Skripsi Sarjana Peternakan. Fakultas Peternakan Universitas Gadjah Mada, Yogyakarta.

Sarwono, B. 2007. Beternak Kambing Unggul. Penebar Swadaya, Jakarta.
Serment, A., P. Schmidely, S. Giger-Reverdin, P. Chapoutot and D. Sauvant. 2011. Effects of the percentage of concentrate on rumen fermentation, nutrient digestibility, plasma metabolities, and milk composition in midlactation goats. J. Dairy Sci. 94: 3960-3972.

Sholikhin, W. I. 2010. Perbandingan konsumsi pakan dan pertambahan bobot badan kambing Bligon dan kambing Kejobong jantan. Skripsi Sarjana Peternakan. Fakultas Peternakan, Universitas Gadjah Mada, Yogyakarta.

Sumoprastowo, C. D. A. 1993. Beternak Kambing yang Berhasil. Bharata Karya Aksara, Jakarta.

Tahuk, P. K. 2008. Kinerja kambing Bligon jantan pada penggemukan dengan level protein kasar berbeda. Tesis. Fakultas Peternakan Universitas Gadjah Mada, Yogyakarta.

Tillman, A. D., H. Hartadi, S. Reksohadiprodjo, S. Prawirokusumo, dan S. Lebdosoekojo. 1998. Ilmu Makanan Ternak Dasar. Gadjah Mada Univesity Press, Yogyakarta.

Utomo, R. dan M. Soejono. 1999. Bahan Pakan dan Formulasi Ransum. Jurusan Nutrisi dan Makanan Ternak. Fakultas Peternakan Universitas Gadjah Mada, Yogyakarta. 